\title{
THE STATE OF COMPETITION OF THE TURKISH BANKING INDUSTRY: AN APPLICATION OF THE PANZAR-ROSSE MODEL
}

\author{
Bora Aktan*1, Omar Masood ${ }^{2}$ \\ ${ }^{1}$ Yasar University, Faculty of Economics and Administrative Sciences, \\ Finance Department, Selcuk Yasar Campus, 35100, Izmir, Turkey \\ ${ }^{2}$ University of East London Business School, Docklands Campus, \\ University Way, E16 2RD, United Kingdom. \\ E-mail:1bora.aktan@yasar.edu.tr,2o.masood@uel.ac.uk
}

Received 3 February 2009; accepted 20 January 2010

\begin{abstract}
This paper examines the competitive structures of the Turkish banking industry over the period 1998-2008 and investigates the factors that can explain differences in the degree of competitiveness. The Panzar-Rosse method is used to test for the competitive nature of the industry, which also gives the measure of competition, the $H$-statistic, is related to a number of industry controls and prevailing banking structures. Our results indicate that the banking industry in Turkey is in an equilibrium state, further they are in long run equilibrium. We also found that the banks in Turkey are operating as a whole under conditions of monopolistic competition. However, the banks were able to achieve high records of profitability in monopolistically competitive markets.
\end{abstract}

Keywords: banking, bank competition, Panzar-Rosse h-statistic, equilibrium tests, Turkey.

Reference to this paper should be made as follows: Aktan, B.; Masood, O. 2010. The state of competition of the Turkish banking industry: an application of the Panzar-Rosse model, Journal of Business Economics and Management 11(1): 131-145.

\section{Introduction}

In recent years, a continuously increasing number of papers have investigated competition in the banking industry. Globalizations and the liberalization of financial markets have raised broad interest in this topic. Obviously, competition in the banking sector has a major impact on the wealth of consumers and companies and affects the performance and financial condition of the banks. This further initiated the mergers among banks and other financial institutions causing drastic changes and competition in the structure of the banking industry.

Turkish banking industry forms a great part of the whole financial system in the country's dynamic economy. Most of the transactions and activities of money and capital

\footnotetext{
* Corresponding Author
} 
markets are carried out by banks. Most State banks were established to finance a particular industry such as agriculture i.e., Ziraat Bank, but private banks generally have close connections to large industrial groups and holdings.

How have competitive conditions in Turkey changed the overall banking and regulations in the country in the last decade? By the scope of this paper, we answer this question by using econometric techniques to examine the nature of competitive conditions in the market of the major Turkish banks.

One of the most popular methods used to assess the competition in the banking industry is the Panzar and Rosse Model. Seminal articles by Rosse and Panzar (1977), Panzar and Rosse $(1982,1987)$ provide an excellent framework for assessing degrees of competition in the banking industry. However, the empirical translation of this approach into an econometric specification is ambiguous and allows for some degrees of freedom. The model uses cross-sectional data to assess the competitive behavior of banks based on the comparative static properties of reduced-form revenue equations. It explains revenues from input prices, among other factors. In this setting, the sum of the elasticities of a bank's total revenues to its input prices provides a pivotal statistic to test for monopoly and perfect competition. Moreover, under certain assumptions this statistic can also serve as a measure of the degree of competition in the banking sector.

The motivation behind our research is, limited literature tackling the market structure of the Turkish banking sector. This study contributes to the literature on market structure in Turkish banking systems by using a larger sample of banks over a significant amount of time. As we measure the competitiveness through our dataset collected from 17 major banks in the Turkish banking sector. It helps us to relate the contestability indicators and to explain differences in the degree of competition across Turkey. The aim of this research is to provide empirical evidence on the level and evolution of competition in the Turkish sector. For this purpose, we employ Panzar-Rosse model, which enables calculation of a measure of market structure, the $H$-statistic, as the sum of the elasticities of total revenues of the bank with respect to its input prices.

The paper is organized as follows: Following the introduction, Section 2 discusses the previous studies, Section 3 presents a brief situation of the Turkish banking system, Section 4 introduces the Panzar-Rosse Model and the characteristic of the data used in the paper, Section 5 provides the empirical findings and Section 6 finally concludes with a short summary.

\section{Previous Studies}

The theory of contestable markets developed by Baumol et al. (1982) stated that oligopolies and monopolies sometimes behave very much like perfectly competitive firms. There have been few applications of the contestable markets theory on the banking industry. Studies by Shaffer (1982, 1983, 1994), Nathan and Neave (1989) and Molyneux et al. $(1994,1996)$ are the most significant among many others. They employed tests developed by Rosse and Panzar (1977) and Panzar and Rosse (1987) to examine the competitive conditions in the banking industry in the U.S., Canada, Japan and Europe. 
Nathan and Neave (1989) found some evidence that the U.S and Canadian banking markets exhibit characters of contestability.

Shaffer (1982) reported the first application of the Panzar-Rosse test to banking data, obtaining $0<\mathrm{H}<1$ for a sample of banks based in New York. Using European banking data for 1986-89, Molyneux et al. (1994) obtained $0<\mathrm{H}<1$ for France, Germany, Spain and the UK, and $\mathrm{H}<0$ for Italy. Using 1992-96 data, De Bandt and Davis (2000) obtained $0<\mathrm{H}<1$ for France, Germany, Italy and the US. Similar results were reported by Nathan and Neave (1989) for Canada, Molyneux et al. (1996) for Japan, Staikouras and Koutsomanoli-Fillipaki (2006) for the enlarged European Union. Hondroyiannis et al. (1999) assessed competitive conditions in the Greek banking system in 19931995 and found that the banking industry in Greece had a monopolistic competition. Bikker and Haaf (2002) investigated competitive conditions and concentration in the banking markets of 23 industrialized countries by using Panzar-Rosse model along with Bresnahan (1982) model. Their results reveal that banking markets of the industrialized countries are characterized by monopolistic competition and sometimes even perfect competition cannot be excluded. Casu and Girardone (2006) employed both structural concentration measures and Panzar-Rosse model to investigate competitive conditions in European Union banking markets. Based on their results, while they argue that the degree of concentration is not necessarily related to the degree of competition their $H$-statistic reveals that there is a monopolistic competition in the EU market. CarboValverde et al. (2009) employed five different measures including Panzar-Rosse $H$ statistic to determine the degree of competition in 14 European banking industries. Their analysis yields conflicting results contingent upon the competition indicator employed. Thus, they argued that it is essential to employ a range of different competition measures to determine competition behavior of countries and the studies should consider country specific factors as well.

While most of the early applications of Panzar-Rosse model mainly focused on the developed countries' banking industries, more recent ones apply the model to the other markets (e.g. Masood and Aktan 2010; Celik and Urunveren 2009; Turk-Ariss 2009; Yuan 2006; Gunalp and Celik 2006; Kasman 2001). Gelos and Roldós (2004) applied Panzar-Rosse methodology on a sample of eight emerging markets including Argentina, Brazil, Chile, Czech Republic, Hungary, Mexico, Poland and Turkey. Their results indicate that market structure for the majority of countries can be characterized by monopolistic competition and the banking industries in the sample have not become less competitive. Kasman (2001) and Gunalp and Celik (2006) assessed the competition in the Turkish banking industry by using Panzar-Rosse $H$ statistic and concluded that Turkish banks show a monopolistic competition. While the competition of the Latin American countries banking industries is found to be monopolistic by Yildirim and Philippatos (2007a), Yeyati and Micco (2007) investigated the concentration and foreign penetration on the competitive behavior of the Latin American banking industries including Argentina, Brazil, Chile, Colombia, Costa Rica, El Salvador, Mexico and Peru. They found that while concentration had no weakening effect on competition, foreign penetration led to a less competitive banking industry in the region. Yildirim and Philippatos 
(2007b) examined the competitive conditions in the banking industries of 14 Central and Eastern European (CEE) transition economies for the period 1993-2000. The countries in the sample include: Bulgaria, Czech Republic, Estonia, Croatia, Hungary, Latvia, Lithuania, FYR of Macedonia, Poland, Romania, Slovenia, Slovak Republic, Russian Federation and Yugoslavia. The paper argue that the banking markets of the countries in the sample (except for Macedonia and Slovakia) cannot be characterized by either perfect competition of monopoly ${ }^{1}$.

According to Blaug (1980: 118), "traditional microeconomics is largely, if not entirely, an analysis of timeless comparative statics, and as such it is strong on equilibrium outcomes but weak on the process whereby equilibrium is attained". Schumpeter (1954) regarded static theory as operating at a higher level of abstraction than dynamic theory. Goddard et al. (2004a, b) found that convergence towards long-run equilibrium is by no means instantaneous. Berger et al. (2000) reached a similar conclusion by using non-parametric techniques to measure persistence.

The New Empirical Industrial Organization (NEIO) assesses the strength of market power by examining deviations between the observed and the marginal cost pricing, without explicitly using any market structure indictor. The Rosse and Panzar (1977) reduced-form revenue model and the Bresnahan (1982) and Lau (1982) mark-up model are two the most popular approaches to this type of analysis.

The Panzar-Rosse approach works well with firm-specific data on revenues and factor prices, and does not require information about equilibrium output prices and quantities for the firm and/or industry. In addition, the Panzar-Rosse approach is robust in small samples, while the Bresnahan-Lau model tends to exhibit an anticompetitive bias in small samples (Shaffer 2004). Rosse and Panzar (1977) and Panzar and Rosse (1982, 1987), together with applications to banking by Nathan and Neave (1989) and Perrakis (1991), assumed that firms can enter or leave any market rapidly, without losing their capital, and that potential competitors operate on the same cost functions as established firms.

Most previous studies that have employed the Panzar-Rosse methodology have used data sets containing large numbers of banks and small numbers of periods. The Panzar-Rosse methodology is only one of the numerous ways to measure the nature of competitive conditions. Uchida and Tsutsui (2005) used the Cournot oligopoly version of the Monti-Klein model of the banking firm to derive a loan interest rate setting function in terms of the cost of funds and marginal operational costs of servicing loans and deposits $^{2}$. Matthews et al. (2007) found evidences that the intensity of competition in the core market of bank lending for British banks remained approximately unchanged throughout the 1980s and 1990s. They also argued that competition appears to have become less intense in the non-core (off-balance sheet) business of British banks.

\footnotetext{
${ }^{1}$ In previous studies regarding market concentration, competition has been measured by using concentration indices such as the Herfindahl index (see for a broad discussion Ginevičius and Čirba 2007, 2009).

${ }^{2}$ For a discussion of the theoretical literature see, Freixas and Rochet (1997).
} 
One of the limitations of the Panzar-Rosse tests is that it gives misleading results when the banks in question are not completely adjusted to the market conditions. However, the test generally indicates that the market is competitive, it checks that the monopoly power is not been excersied. Secondly, it cannot differentiate between competitive pricing and simple costing plus pricing. Interpreting the Panzar-Rosse is not very clear, once this limitation taken into account.

\section{The Turkish Banking Industry}

Financial system in Turkey is largely dominated by commercial banks which many transactions and activities in both money and capital markets are carried out therefore, its banking sector is virtually synonymous with the entire system on account of the country's economic and historical development. As all the major economies of the world are reeling under the pressure of financial crisis, the banking industry in Turkey continued to grow in 2008 and foreign participation also increased. Recent economic and financial reforms providing positive atmosphere and attractiveness for growth encouraged many foreign banks enter into the sector with full banking activities while forced existing banks to restructure their organizations, operations and activities (Aktan et al. 2009a).

Banks operating in Turkey can be classified under three main groups as those with the permission to accept deposits (commercial or deposit banks), those not accepting deposits (non-deposit or development and investment banks) and participation banks which are based upon interest-free banking (Profit/Loss Sharing). Besides, each group can be divided into three sub-groups as state-owned, privately owned, and foreign banks according to their ownership structures. As of December 2008, the number of banks operating in Turkey was 49. 32 of them were in deposit banks group, 13 of them were non-deposit banks and 4 of them were participation banks. Among deposit banks, there were 3 state-owned banks, 11 privately-owned banks, 17 foreign banks and one bank, under the supervision of the Savings Deposit Insurance Fund (SDIF) with 8791 branches including those abroad. In addition, 17 of the banks are listed on the Istanbul Stock Exchange (BAT 2008).

By the end of 2008, total assets of banking sector amounted to TRY 732.7 billion ( $\$$ 481.5 billion USD). When the asset distribution of the sector is analyzed, it is seen that $3.6 \%$ of total assets of the sector is comprised of non-current assets in the period examined. The share of cash and quasi-cash assets in total balance sheet size was realized as $12.9 \%$ level while the share of loans in total assets was $50.3 \%$ and the share of securities portfolio in total assets was realized as $26.5 \%$. The total loans of the sector were TRY 367.6 billion ( $\$ 241.5$ billion USD). On the other hand, total deposit of the sector amounted TRY 454.6 billion ( $\$ 298.7$ billion USD) while net profit of the period was TRY 13.3 billion ( $\$ 8.74$ billion USD) (BRSA 2009) 3 .

\footnotetext{
${ }^{3}$ Central Bank of the Republic of Turkey FX buying rates are used for conversion as of 31 December 2008.
} 
The crisis of 1999-2001 is rooted in the institutional development of the regulatory and supervisory mechanisms in the Turkish banking sector. Deposit insurance was introduced in 1983 in the aftermath of the massive collapse of savings and loans institutions. The 1985 law on banking regulations (Banking Act No. 3182), which retroactively formalized the limited deposit insurance and made the Treasury the principle institution responsible for bank supervision and regulation, represented the first major attempt at regulating the banking sector.

Legislation making deposit insurance more generous contributed to the banking sector's problems. Initially the coverage was limited to $100 \%$ of Turkish lira deposits up to a legally set maximum and 60 percent thereafter (Banks Act No. 3182). In 1992, the coverage was extended to foreign currency accounts. Finally, on May 5, 1994 after the banking crisis and a run on banks, the Treasury eliminated the cap and declared 100 percent insurance on all deposits. Although this helped to stabilize the banking sector during the 1994 crisis, it also encouraged further risky behavior leading up to the crisis in 1999.

In addition, financial sector regulators and supervisors lacked autonomy, making them susceptible to political and industry pressure. Furthermore, basic accounting, auditing and disclosure practices were also significantly below international best practice (Aktan et al. 2009b). Honohan (1997), for example, emphasizes that Turkey's 100\% deposit guarantee and a tradition of forbearance instead of firm corrective action encouraged excessive risk taking, increased moral hazards and weakened market discipline. Alper and Onis (2002) argue that the destruction of bank franchise values was the result of heavy government intervention and unfair competition.

The severe banking crisis in 1999 highlighted the need for instituting an autonomous and independent banking supervisory and regulatory framework. The formation of the Banking Regulation and Supervisory Agency (BRSA) in 1999 was an important milestone in banking regulation in Turkey. As an independent regulatory agency, BRSA was somewhat insulated from the political pressures that plagued the supervisory functions of the Treasury. There is some doubt about the extent of its independence, however. According to Alper and Onis (2002) the organization is not entirely isolated from political intervention since the Cabinet appoints its chairman and board members. In fact, in 2000, the appointment of the first board bitterly divided the governing coalition and the final decision was repeatedly delayed and only approved because it was a "structural performance criterion", which had to be met to qualify for financial assistance from the International Monetary Fund (IMF). After the crisis of February 2001, the autonomy and political independence of the BRSA was called into doubt when the IMF requested the dismissal of the first set of board members. In general, following the above-stated crisis and the restructuring process, the banking sector showed a rapid growth performance in 2002-2008 period and the risk management systems improved and public supervision became more effective in Turkey. 


\section{Data and Method}

\subsection{The Data}

The data used in this study were obtained from Datastream and also collected from 17 significant banks of Turkey which are all listed on the Istanbul Stock Exchange (ISE), including Akbank TAS, Albaraka Turk, Alternatifbank AS, Asya Katilim Bankasi AS, Denizbank AS, Finansbank AS, Fortis Bank AS, Sekerbank TAS, Tekstil Bankasi AS, Turk Ekonomi Bankasi AS, Turkiye Garanti Bankasi AS, Turkiye Halk Bankasi AS, Turkiye Is Bankasi AS, Turkiye Kalkinma Bankasi AS, Turkiye Sinai Kalkinma Bankasi AS, Turkiye Vakiflar Bankasi TAO, Yapi ve Kredi Bankasi AS. The dataset was developed by collecting the information related to these banks.

The pooled data was made by combining the datasets from all the banks covering the period 1998-2008. The regression analysis was performed on this pooled data to obtain the results which are mentioned in the next section. The mean square and double accounting techniques were also used on the dataset, wherever required.

\subsection{The Model}

The test developed by Panzar-Rosse examines the relationship between examines a relationship between input prices and equilibrium gross revenue derived from the theory of the firm under some assumptions about competitive conditions. They showed that the sum of the elasticities of the reduced form revenue function with reduced prices is a measure of competitive conditions.

Panzar-Rosse assumed long run equilibrium equations on firm's revenue and input price vectors. Their approach was to measure the effect of factor prices on the observed equilibrium values of total revenue $R$. If $R$ is the observed revenue and $w_{i}$ is the price of $i^{t h}$ input, where $i=1,2,3 \ldots n$, then the test quantity of $H$ (The Rosse-Panzar $(P-R)$ $H$ statistics) is

$$
P-R_{H}=\sum_{i=1}^{n} \frac{\delta R w_{i}}{\delta w_{i} R} .
$$

In the Rosse and Panzar (1977) and Panzar and Rosse (1987) there are four features. Firstly, under the monopoly equilibrium, sum of the factor prices elasticities of a monopolist's reduced form revenue must be non-positive. Secondly under monopolistic equilibrium sum of elasticities of the of the firm's reduced form revenues with respect to factor prices is less than or equal to unity. Thirdly, for the firms in long run equilibrium the sum of elasticities of the reduced form revenues with respect to factor prices of the firm must be equal to unity. Finally, for the firms in stable, conjectural variation oligopoly equilibrium, the sum of factor price elasticities of reduced form output equation is negative.

In order to test the monopolistic competition Panzar and Rosse (1987) follow the assumption regarding the way the firm's revenue gets repositioned by market forces after an input change. Panzar-Rosse relies on the fact that individual banks prices in response to changes in cost, which also depends weather the banks enjoys a monopoly market or instead is facing a competitive market. 
If the banks have a monopoly power and sets its prices to maximum profits, it chooses price so that its gross revenue responds in opposite direction from a change in unit costs. If the market is perfectly competitive, the industries gross revenues could rise or fall, depending on the demand factors, but the banks entry or exit would force each existing bank's revenue to change in same direction as its unit costs.

The Panzar-Rosse model can be interpreted by the help of the below Table 1 provided by Hondroyiannis et al. (1999).

Table 1. The theory and interpretation of the Panzar-Rosse $H$ statistic

\begin{tabular}{ll}
\hline Equilibrium Test \\
\hline $\mathrm{E}=0$ & Equilibrium \\
\hline $\mathrm{E}<0$ & Disequilibrium \\
\hline Competitive Conditions Test \\
\hline $\mathrm{H} \leq 0$ & Monopoly or conjectural variations short run oligopoly \\
\hline $\mathrm{H}=1$ & $\begin{array}{l}\text { Perfect competition or natural monopoly in a perfectly contestable market or sales } \\
\text { maximizing firm subject to a break even constraint }\end{array}$ \\
\hline $0<\mathrm{H}<1$ & Monopolistic competition \\
\hline
\end{tabular}

Rosse and Panzar (1977), Panzar and Rosse (1982, 1987) show that when the H-statistic is negative $(\mathrm{H}<0)$ the structure of the market is monopolistic. This case includes oligopoly with collusion, and may include a conjectural variation short-run oligopoly. In such cases, an increase in input prices will increase marginal costs, reduce equilibrium output and reduce total revenue. An $\mathrm{H}$-statistic of one $(\mathrm{H}=1)$ is associated with perfect competition, as any increase in input prices increases both marginal and average costs, without altering the optimal output of any individual firm. This case also includes a natural monopoly operating in a perfectly contestable market, and a sales-maximizing firm subject to break-even constraints. Finally, $0<\mathrm{H}<1$, is associated with monopolistic competition.

According to the Panzar-Rosse methodology, measure of market structure is calculated as sum of the elasticities of total revenues of the bank with respect to its input prices. It is estimated from the following:

$$
\ln (T R)=\alpha+\beta_{1} \ln W_{L}+\beta_{2} \ln W_{F}+\beta_{3} \ln W_{K}+\gamma_{1} \ln Y_{1}+\gamma_{2} \ln Y_{2}+\gamma_{3} \ln Y_{3}+\varepsilon,
$$

where:

$T R=$ Total Revenue

$W_{L}=$ Ratio of Personnel Expenses to Total Assets

$W_{F}=$ Ratio of Interest Expenses to Total Deposits

$W_{K}=$ Ratio of Other Operating and Administrative Expenses to Total Assets

$Y_{1}=$ Ratio of Equity to Total Assets

$Y_{2}=$ Net Loans to Total Assets

$Y_{3}=$ Total Assets 
Various assumptions are required to be made to apply to the Panzar-Rosse methodology such as, banks are treated as single product firms, acting exclusively as financial intermediaries that produce interest revenues using labor, capital and intermediated funds (mainly deposits) as inputs. Moreover it is assumed that higher factor prices are not correlated with higher revenues generated by higher quality services, since this may bias the computed $H$-statistic.

$$
\ln (R O A)=\alpha+\beta_{1} \ln W_{L}+\beta_{2} \ln W_{F}+\beta_{3} \ln W_{K}+\gamma_{1} \ln Y_{1}+\gamma_{2} \ln Y_{2}+\gamma_{3} \ln Y_{3}+\varepsilon,
$$

where $R O A=$ Return on Assets.

In the Panzar-Rosse framework, banks should be observed from a long-run equilibrium perspective. The equilibrium statistic $\varepsilon$ is calculated as the sum of the input price elasticities, and the hypothesis that its value is 0 is tested where, if rejected, the market is not in equilibrium.

\section{Empirical Analysis}

The equilibrium tests and the competitive conditions tests for pooled data regressions on the data sample for Turkish banks over a period of 1998-2008 are shown in the Tables 2 and 3 respectively.

The equilibrium conditions are tested using the estimation of $\ln R O A$. The results show that it yields a R-squared value of 0.59 . This suggests that the variables that we use have a very small impact on the variation in $\operatorname{lnROA}$. We also observe that the regression coefficients are positive, with $\ln \mathrm{W}_{\mathrm{F}}$ significant at $5 \%$ level.

Table 2. Equilibrium test results for Turkish banks for 1998-2008

(Depended variable - $\ln R \mathrm{OA}$ )

\begin{tabular}{ll}
\hline Coefficients & Turkey \\
\hline $\ln W_{L}$ & $0.035(0.081)$ \\
\hline $\ln W_{F}$ & $0.136(0.066)$ \\
\hline $\ln W_{K}$ & $0.054(0.041)$ \\
\hline $\ln Y_{1}$ & $0.026(0.017)^{* *}$ \\
\hline $\ln Y_{2}$ & $0.071(0.042)$ \\
\hline $\ln Y_{3}$ & $0.011(0.024)$ \\
\hline $\mathrm{R}^{2}$ & 0.59 \\
\hline E-statistic & $-0.048(0.08)$ \\
\hline equilibrium $E=0$ & Fail to Reject \\
\hline
\end{tabular}

Notes: ${ }^{* * *}$ and ${ }^{* *}$ denotes that the values are significant at 10\% level and 5\% level respectively

Robust standard errors are reported in parentheses
Table 3. Competitive conditions test results for Turkish banks for 1998-2008

(Depended variable $-\ln$ TR)

\begin{tabular}{ll}
\hline Coefficients & Turkey \\
\hline $\ln W_{L}$ & $0.38(0.085)^{* * *}$ \\
\hline $\ln W_{F}$ & $0.331(0.049)^{* * *}$ \\
\hline $\ln W_{K}$ & $0.069(0.017)^{* *}$ \\
\hline $\ln Y_{1}$ & $0.044(0.053)$ \\
\hline $\ln Y_{2}$ & $-0.009(0.069)$ \\
\hline $\ln Y_{3}$ & $0.018(0.029)$ \\
\hline $\mathrm{R}^{2}$ & 0.79 \\
\hline PR H-statistic & $0.753(0.098)$ \\
\hline Monopoly H=0 & Reject ${ }^{* * *}$ \\
\hline Perft. Comp. H=1 & Fail to Reject ${ }^{* * *}$ \\
\hline $\begin{array}{l}\text { Notes: }{ }^{* * *} \text { and }{ }^{* *} \text { denotes that the values are sig- } \\
\text { nificant at } 10 \% \text { level and 5\% level respectively }\end{array}$ \\
$\begin{array}{l}\text { Robust standard errors are reported in parentheses }\end{array}$
\end{tabular}


From the above table we observe that E-statistic of -0.048 , hence we are unable us to reject the null hypothesis at $10 \%$ level. We tested by running a rolling regression of a 11-year window with the aim of identifying whether the banking market was in equilibrium or not. Our results indicate that Turkey banking sector is in an equilibrium state. The calculated $E$-statistic is not significantly different from 0 at the $95 \%$ level for Turkey. The banking markets are thus in long-run equilibrium.

The Panzar-Rosse $H$-statistic indicates that banks in Turkey are operating as a whole under conditions of monopolistic competition. A monopolistic competition structure is the existence of product differentiation in banking and with the fact that banks tend to differ with respect to product quality and advertising.

The competitive conditions are tested using the estimation of $\ln$ TR. The results show that it yields a R-squared value of 0.79 . This suggests that the variables that we use have a very small impact on the variation in $\ln T R$. By our results we can conclude that market power resulting from high concentration levels does not exclude competitive behavior. This suggests that the degree of competition in banking may be affected by different factors for differences.

Now we consider the factors which affect the degree of competition. The sample consists of panel data for the individual profiled countries over the period 1998-2008. The models are estimated following equation given below:

$$
H_{i}=a+b C_{i}+e,
$$

where:

$H_{i}=$ Degree of competition,

$C_{i}=$ Vector of variables.

The variables are obtained from Barth et al. (2007), Economist Intelligence Unit Country Profiles and Turk-Ariss (2009). Ci (vector of variables) is classified into two categories, including industry control factors and indicators of banking structures. Industry control variables include three variables efficiency, profitability and capitalization levels whereas indicators of banking structures include bank concentration foreign ownership. The description of the variables is given in the Table 4.

The estimation results on these variables reported in Table 5. Panel A considers the yearly-derived H-statistic as dependent variable, and panel B uses the overall H-statistic as the dependent variable.

We observe that the sign of all the models of the industry controlled variables is negative. This indicates that Turkish banks which operate in more monopolistic environments are also less efficient. Our findings are similar to Turk-Ariss (2009), but different to Casu and Girardone (2006), who argue that banks in more competitive markets are also more efficient. We found profitability was positive for all the models, indicating that banks were able to achieve high records of profitability in monopolistically competitive markets.

The capitalization is also found positive, which indicates that lesser capitalized banks were not able to operate better in competitive markets. We observe a negative but in- 
Table 4. Description of variables which affect degree of competition

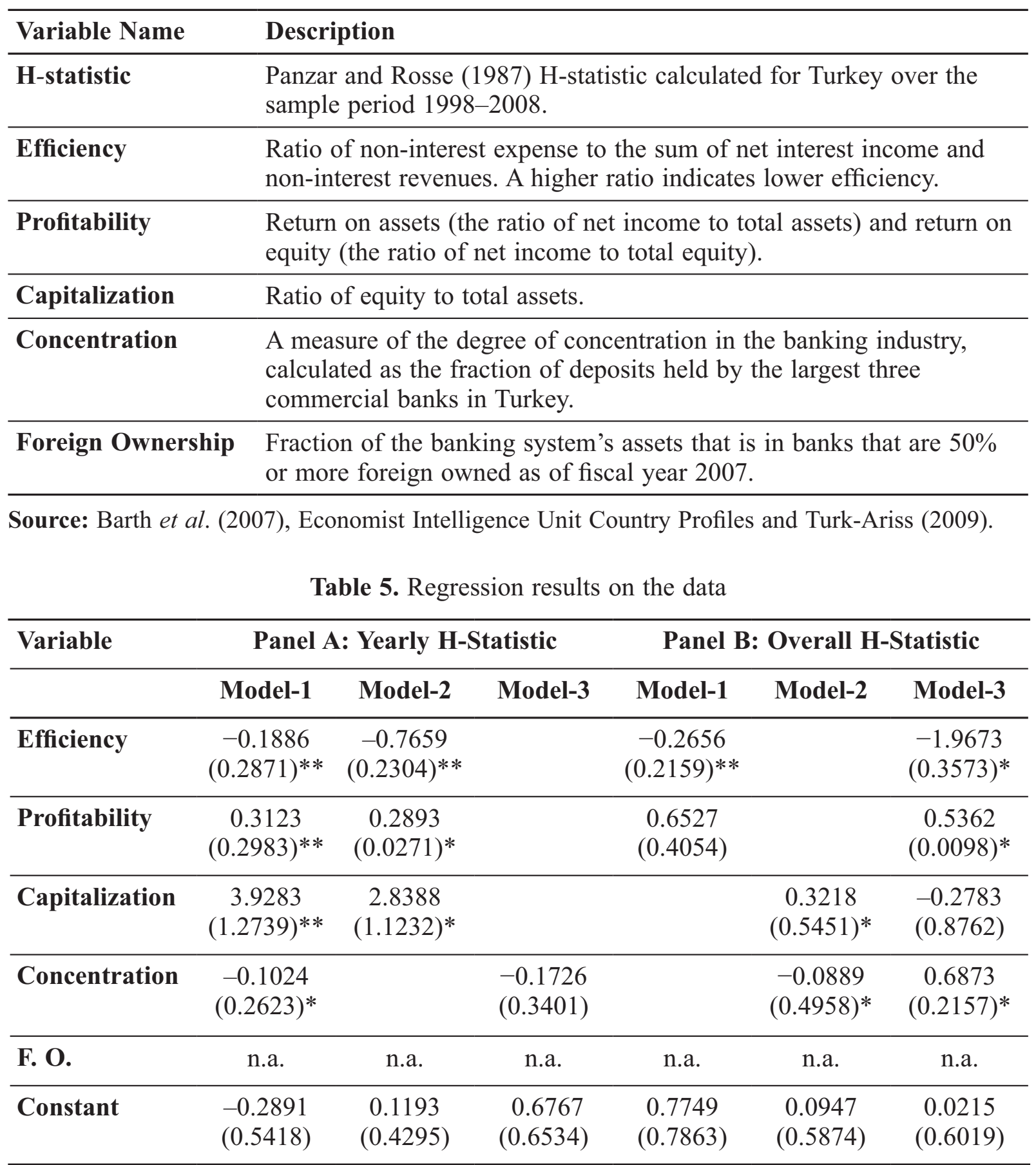

Notes: $* * *, * *$ and $*$ denotes that the values are significant at $10 \%$ level, $5 \%$ level and $1 \%$ respectively Robust standard errors are reported in parentheses F.0. - Foreign Ownership

significant relationship between concentration and competition. This indicates that the degree of competition increases with increases in market concentration across Turkish banking sectors. It can therefore be concluded that due to high concentration in the Turkish banking system in the last decade, the market power for the leading firms have reduced. Our results are henceforth in line with Casu and Girardone (2006) but opposite to Claessens and Laeven (2004) who found a positive association between concentration and competition. 


\section{Final Remarks}

This paper examines competitive structures of 17 paramount banks in the Turkish banking sectors over the period 1998-2008 and investigates factors that can explain differences in the degree of competitiveness. The Panzar-Rosse methodology is used to test for the competitive nature of banking sector and also gives the measure of competition, the $H$-statistic, is related to a number of industry controls and prevailing banking structures.

Our results indicate that Turkey banking sector is in an equilibrium state, further they are in long run equilibrium. According to the findings, which seem consistent with the previous studies' findings (Kasman 2001; Gunalp and Celik 2006) on the industry, the banks in Turkey are operating as a whole under conditions of monopolistic competition. Moreover, we observed that market power resulting from high concentration levels in Turkey does not exclude competitive behavior. This suggests that the degree of competition in banking was affected by different factors for differences.

We found that Turkish banks, which operate in more monopolistic environments, are also less efficient; however the banks were able to achieve high records of profitability in monopolistically competitive markets. The banks with small capital base were not able to operate better in competitive market. Henceforth we conclude that due to high concentration in the Turkish banking system in the last decade, the market power for the leading firms has reduced.

\section{References}

Aktan, B.; Teker, E.; Ersoy, P. 2009a. Changing face of banks and the evaluation of internet banking in Turkey, Journal of Internet Banking and Commerce 14(1): 1-11.

Aktan, B.; Masood, O.; Yilmaz, S. 2009b. Financial shenanigans and the failure of ethics in banking: a review and synthesis of an unprecedented fraud, Banks and Bank Systems 4(1): 31-37.

Alper, C. E.; Onis, E. 2002. Soft budget constraints, government ownership of banks and regulatory failure: the political economy of the Turkish banking system in the post-capital account liberalization era, Bosphorus University, Economic Departmental Working Paper, No. 02/2002, Istanbul, Turkey, February 2002.

Barth, J.; Caprio, G.; Levine, R. 2007. The regulation and supervision of banks around the world: a new database, World Bank Policy Research Working Paper, No. WPS 2588.

BAT 2008. Banks, Branches and Employes. Statistical Reports, December 2008. The Banks Association of Turkey (BAT) [online] [cited 3 February 2009]. Available from Internet: <www.tbb.org.tr>. BRSA 2009. Monthly Bulletin, Year 5, No. 46, February.

Baumol, W. J.; Panzar, J. C.; Willig, R. D. 1982. Contestable Markets and the Theory of Industry Structure. Harcourt Brace Jovanovich, Inc., New York.

Berger, A. N.; Bonime, S. D.; Covitz, M. D.; Hancock, D. 2000. Why are bank profits so persistent? The roles of product market competition, information opacity and regional macroeconomic shocks, Journal of Banking and Finance 24(7): 1203-1235. doi:10.1016/S0378-4266(99)00124-7 Bikker, J. A.; Haaf, K. 2002. Competition, concentration and their relationship: an empirical analysis of the banking industry, Journal of Banking \& Finance 26(11): 2191-2214.

doi:10.1016/S0378-4266(02)00205-4 
Blaug, M. 1980. The Methodology of Economics. Cambridge UK: Cambridge University Press. Bresnahan, T. F. 1982. The oligopoly solution identified, Economics Letters 10(1-2): 87-92. doi:10.1016/0165-1765(82)90121-5

Carbo-Valverde, S.; Rodriguez-Fernandez, F.; Udell, G. F. 2009. Bank market power and SME financing constraints, Review of Finance 13(2): 309-340. doi:10.1093/rof/rfp003

Casu, B.; Girardone, C. 2006. Bank competition, concentration and efficiency in the single European market, The Manchester School 74(4): 441-468. doi:10.1111/j.1467-9957.2006.00503.x

Celik, T.; Urunveren, C. 2009. Yabancı banka girişlerinin türk bankacilik sektörüne rekabet etkisi 2002-2007, Nigde University, Journal of Economics \& Administrative Sciences 2: 42-59 (in Turkish).

Claessens, S.; Laeven, L. 2004. What drives bank competition? Some international evidence, Journal of Money, Credit and Banking 36(2): 563-584. doi:10.1353/mcb.2004.0044

De Bandt, O.; Davis, E. P. 2000. Competition, contestability and market structure in European banking sectors on the eve of the EMU, Journal of Banking \& Finance 24(6): 1045-1066. doi:10.1016/S0378-4266(99)00117-X

Freixas, X.; Rochet, J. C. 1997. Microeconomics of Banking. MIT Press, Cambridge, MA.

Gelos, G.; Roldós, J. 2004. Consolidation and market structure in emerging market banking systems, Emerging Markets Review 5(1): 39-59. doi:10.1016/j.ememar.2003.12.002

Ginevičius, R.; Čirba, S. 2007. Determining market concentration, Journal of Business Economics and Management 8(1): 3-10.

Ginevičius, R.; Čirba, S. 2009. Additive measurement of market concentration, Journal of Business Economics and Management 10(3): 191-198. doi:10.3846/1611-1699.2009.10.191-198

Goddard, J.; Molyneux, P.; Wilson, J. O. S. 2004a. Dynamics of growth and profitability in banking, Journal of Money, Credit and Banking 36: 1069-1090. doi:10.1353/mcb.2005.0015

Goddard, J.; Molyneux, P.; Wilson, J. O. S. 2004b. The profitability of European banks: a crosssectional and dynamic panel analysis, The Manchester School 72: 363-381.

doi:10.1111/j.1467-9957.2004.00397.x

Gunalp, B.; Celik, T. 2006. Competition in the Turkish Banking Industry, Applied Economics 38: 1335-1342. doi:10.1080/00036840500405656

Hondroyiannis, G.; Lolos, S.; Papapetrou, E. 1999. Assessing competitive conditions in the Greek Banking System, Journal of International Financial Markets, Institutions and Money 9(4): 377391. doi:10.1016/S1042-4431(99)00017-7

Honohan, P. 1997. Banking system failures in developing and transition countries: diagnosis and prediction, BIS Economic Papers No. 39, January.

Kasman, A. 2001. Competitive conditions in the Turkish banking industry, Ege Academic Review 1(2): 72-82.

Lau, L. 1982. On identifying the degree of competitiveness from industry, price and output data, Economics Letters 10(1-2): 93-99. doi:10.1016/0165-1765(82)90122-7

Masood, O.; Aktan, B. 2010. Market structure and competitive conditions of banking industry in KSA: The Panzar-Rosse approach, Actual Problems of Economics, January 1(103): 263-276.

Matthews, K.; Murinde, V.; Zhao, T. 2007. Competitive conditions among the major British banks, Journal of Banking \& Finance 31(7): 2025-2042. doi:10.1016/j.jbankfin.2006.11.009

Molyneux, P.; Thornton, J.; Lloyd-Williams, M. D. 1996. Competition and market contestability in Japanese commercial banking, Journal of Economics and Business 48(1): 33-45.

doi:10.1016/0148-6195(95)00047-X

Molyneux, P.; Lloyd-Williams, M. D.; Thornton, J. 1994. Competitive conditions in European banking, Journal of Banking \& Finance 18(3): 445-4 59. 
Nathan, A.; Neave, E. 1989. Competition and contestabilty in Canada's financial system: empirical results, The Canadian Journal of Economics 22: 576-594. doi:10.2307/135541

Panzar, J.; Rosse, J. 1987. Testing for monopoly equilibrium, Journal of Industrial Economics 35: 443-456.

Panzar, J.; Rosse, J. 1982. Structure, conduct and comparative statistics, Bell Laboratories Economic Discussion Paper No. 248. doi:10.2307/2098582

Perrakis, S. 1991. Assessing competition in Canada's financial system: A Note, The Canadian Journal of Economics 22(3): 727-732.

Rosse, J. N.; Panzar, J. C. 1977. Chamberlin Versus Robinson: An Empirical Test for Monopoly Rents. Research Papers No 77. Stanford University, Stanford California.

Schumpeter, J. A. 1954. History of Economic Analysis. London: George Allen and Unwin.

Shaffer, S. 2004. Comment on 'what drives bank competition? some international evidence' by Stijin Claessens and Luc Laeven, Journal of Money, Credit, and Banking 36: 585-592. doi:10.1353/mcb.2004.0050

Shaffer, S. 1994. Bank competition in concentrated markets, Business Review March/April: 3-16. Shaffer, S. 1983. Non-structural measures of competition: toward a synthesis of alternatives, Economics Letters 12(3-4): 349-353. doi:10.1016/0165-1765(83)90061-7

Shaffer, S. 1982. A non-structural test for competition in financial markets, in Proceedings of the 20th Conference on Bank Structure and Competition Federal Reserve Bank of Chicago, 225-243.

Staikouras, C.; Koutsomanoli-Fillipaki, A. 2006. Competition and concentration in the New European banking landscape, European Financial Management 12(3): 443-482.

doi:10.1111/j.1354-7798.2006.00327.x

Turk-Ariss, R. 2009. Competitive behavior in Middle East and North Africa banking systems, The Quarterly Review of Economics and Finance 49(2): 693-710. doi:10.1016/j.qref.2008.03.002

Uchida, H.; Tsutsui, Y. 2005. Has competition in the Japanese banking sector improved? Journal of Banking \& Finance 29(2): 419-439. doi:10.1016/j.jbankfin.2004.05.013

Yeyati, L. E.; Micco, A. 2007. Concentration and foreign penetration in Latin American banking sectors: impact on competition and risk, Journal of Banking \& Finance 31(6): 1633-1647. doi:10.1016/j.jbankfin.2006.11.003

Yildirim, H. S.; Philippatos, G. C. 2007a. Restructuring, consolidation and competition in Latin American banking markets, Journal of Banking \& Finance 31(3): 629-639. doi:10.1016/j.jbankfin.2006.06.008

Yildirim, H. S.; Philippatos, G. C. 2007b. Competition and contestability in Central and Eastern European banking markets, Managerial Finance 33(3): 195-209. doi:10.1108/03074350710718275 Yuan, Y. 2006. The state of competition of the Chinese banking industry, Journal of Asian Economics 17(3): 519-534. doi:10.1016/j.asieco.2006.05.001 


\section{KONKURENCIJA TURKIJOS BANKININKYSTĖS SEKTORIUJE: PANZAR-ROSSE MODELIO TAIKYMAS}

\section{B. Aktan, O. Masood}

\section{Santrauka}

Straipsnyje tyrinėjamos konkuruojančios struktūros ir veiksniai, darantys įtaką skirtingam rinkos žaidèjų konkurencingumo laipsniui Turkijos bankininkystès sektoriuje 1998-2008 m. Bankininkystès sektoriaus konkurencijai ịvertinti taikomas Panzar-Rosse metodas. Rezultatai leidžia teigti, kad bankininkystės sektorius Turkijoje yra pusiausvyros būsenos, pereinančios į ilgalaikị etapą. Taip pat nustatyta, kad bankai Turkijoje veikia monopolinès konkurencijos sąlygomis. Šiomis sąlygomis Turkijos bankai sugeba pasiekti aukštą pelningumą.

Reikšminiai žodžiai: bankininkystės sektorius, bankų konkurencija, Panzar-Rosse metodas, pusiausvyros testas, Turkija.

Bora AKTAN is an Assistant Professor of Finance and Deputy Chair of International Trade and Finance Department at Yasar University, Faculty of Economics and Administrative Sciences. Prior to joining the Yasar University, Dr. Aktan worked as both Corporate Strategy and Business Development Director in international firms largely active in Mexico, England and Turkey. Dr. Aktan's current research activity focuses on global investing, financial characteristics and performance of firms in emerging countries, emerging capital markets, energy price volatility, and risk-return trade-off in asset prices, corporate governance and business ethics. He has published in different refereed journals such as Journal of Business Economics and Management, International Research Journal of Finance and Economics, Investment Management and Financial Innovations, Journal of Property Investment and Finance. He is member of some professional bodies such as The International Institute of Forecasters (IIF), The American Finance Association (AFA), The Society for Financial Econometrics (SoFIE) and the Financial Management Association (FMA). Dr Aktan is also on the editorial boards of several international scholarly journals such as Qualitative Research in Financial Markets, Journal of Applied Sciences, Asian Journal of Mathematics and Statistics, Journal of Artificial Intelligence, Academy of Banking Studies Journal, among others. In addition, he serves as a board member of Economics and Financial Affairs Committee for the Aegean Region Chamber of Industry.

Omar MASOOD is the Subject leader of banking and finance group at the University of East London. Studied Economics and accounts as a first degree, followed by a MBA in Finance, TLHEP Degree in Teaching Higher Learning Education Program (TLHEP \& SEDA), and PhD in Risk Management in banking. Dr. Masood has worked as a consultant with the World Bank and as a strategic fund analyst to several banks and other multi-national companies. His research interests include issues related to fund management, banking crisis, behavioural finance, Islamic banking, political risk and international finance. He is the author of a number of research papers which have been published in international journals and conferences. Currently working on several funded projects relating risk and financial management. Also leading a team working for advising HSBC on their fund and risk management issues. Having successfully led teams at both UBS and Goldman Sachs. 